\title{
Genomic comparison of the O-antigen biosynthesis gene clusters of Escherichia coli O55 strains belonging to three distinct lineages
}

\author{
Correspondence \\ Tetsuya Hayashi \\ thayash@med.miyazaki-u.ac.jp
}

Received 15 September 2007

Revised 3 November 2007

Accepted 9 November 2007

\author{
Atsushi Iguchi, ${ }^{1}$ Tadasuke Ooka, ${ }^{2}$ Yoshitoshi Ogura, ${ }_{1}^{1,2}$ Asadulghani, ${ }^{2}$ \\ Keisuke Nakayama, ${ }^{2}$ Gad Frankel ${ }^{3}$ and Tetsuya Hayashi ${ }^{1,2}$ \\ ${ }^{1}$ Division of Bioenvironmental Science, Frontier Science Research Center, University of Miyazaki, \\ 5200 Kiyotake, Miyazaki 889-1692, Japan \\ ${ }^{2}$ Division of Microbiology, Department of Infectious Disease, Faculty of Medicine, University of \\ Miyazaki, 5200 Kiyotake, Miyazaki 889-1692, Japan \\ ${ }^{3}$ Division of Cell and Molecular Biology, Imperial College London, London SW7 2AZ, UK
}

\section{INTRODUCTION}

The O-antigen constitutes the outermost part of the LPS present in the outer membrane of Gram-negative bacteria.

\footnotetext{
Abbreviations: $\mathrm{A} / \mathrm{E}$, attaching and effacing; $\mathrm{CGH}$, comparative genomic hybridization; EAEC, enteroaggregative Escherichia coli; EAF, enteropathogenic Escherichia coli adherence factor; EHEC, enterohaemorrhagic Escherichia coli; EPEC, enteropathogenic Escherichia coli; HGT, horizontal gene transfer; IS, insertion sequence; LEE, locus of enterocyte effacement; NJ, neighbour-joining; T3SS, type III secretion system; SNP, single nucleotide polymorphism.

The GenBank/EMBL/DDBJ accession numbers for the sequences reported in this paper are AB334576-AB334719 (housekeeping genes), AB334558-AB334567 (eae), AB355995-AB356000 (tccP), AB356001 (tccP2), AB334568-AB334575 (fliC) and AB353131AB353133 (O55-antigen gene clusters and their flanking regions). The GEO accession number for the microarray data reported in this paper is GSE8889.
}

A supplementary figure and table are available with the online version of this paper.
The chemical composition and structure of O-antigen exhibit high levels of variation even in a single species. Thus, together with flagellin ( $\mathrm{H}$ antigen) and capsule ( $\mathrm{K}$ antigen), $\mathrm{O}$-antigen is widely used as a surface marker for serotyping of various Gram-negative bacteria. In Escherichia coli, more than 170 O-antigens have so far been identified (Scheutz et al., 2004). In general, most genes required for $\mathrm{O}$-antigen biosynthesis are clustered on the E. coli chromosome between the colanic acid biosynthesis gene cluster and the histidine biosynthesis (his) operon (Reeves et al., 1996). The organization of Oantigen biosynthesis gene clusters is $\mathrm{O}$-antigen-specific. Sequence comparisons in many bacterial species and strains have shown that the variation between $\mathrm{O}$-antigens has been generated by horizontal transfer of a part or the entire O-antigen gene clusters (Cunneen \& Reeves, 2007; Curd et al., 1998; Fegan et al., 2006; Sugiyama et al., 1998; Wang et al., 2002; Xiang et al., 1994). Thus, the serotype of a strain correlates to some extent with its phylogeny, and often provides valuable information on its pathotype. 
Enteropathogenic E. coli (EPEC) and enterohaemorrhagic E. coli (EHEC) are important enteric pathogens for humans. EPEC is the most common bacterial cause of prolonged diarrhoea in infants in unindustrialized countries (Donnenberg et al., 1997; Nataro \& Kaper, 1998), while EHEC, which causes diarrhoea, haemorrhagic colitis and haemolytic uraemic syndrome, is one of the most important intestinal pathogens in industrialized countries (Kaper, 1998; Nataro \& Kaper, 1998). EPEC and EHEC colonize the intestinal epithelia via attaching and effacing (A/E) lesions (Nataro \& Kaper, 1998), which are characterized by the degeneration of the epithelial cell brush border microvilli and the formation of actin-rich pedestals within the host enterocytes beneath the adherent bacteria (Nataro \& Kaper, 1998). Most of the genes required to induce $\mathrm{A} / \mathrm{E}$ lesions are located on the locus of enterocyte effacement (LEE) pathogenicity island (Elliott et al., 1998; Mellies et al., 1999), which encodes the outer-membrane adhesin intimin, a type III secretion system (T3SS), transcriptional regulators, and several T3SS effector proteins including the translocated intimin receptor (Tir).

LEE-positive strains can be classified into several subtypes based on sequence variation within LEE genes (Blanco et al., 2006; Lacher et al., 2006; McGraw et al., 1999; Ogura et al., 2007). Variation in the eae gene, which encodes intimin, has led to classification of more than 25 intimin subtypes (Lacher et al., 2006). Based on the sequence variation in Tir, the protein can be classified into two subtypes (DeVinney et al., 1999): Tir Y-P, which contains a tyrosine residue (Y474 in EPEC E2348/69) that is phosphorylated by host tyrosine kinases (Kenny, 1999) and uses Nck to trigger actin polymerization (Gruenheid et al., 2001), and
Tir-S, which lacks a Y474 equivalent and typically triggers actin polymerization by the TccP pathway (Garmendia et al., 2004). The former is represented by the tir gene of EPEC O127:H6 strain E2348/69 (thus referred to as $\left.\operatorname{tir}_{\mathrm{E} 2348 / 68}\right)$ and the latter by that of EHEC O157:H7 strain Sakai $\left(\right.$ tir $\left._{\text {Sakai }}\right)$ (Ogura et al., 2007). Previous studies have shown that $t i r_{\mathrm{E} 2348 / 68}$ is widely distributed in various EPEC and EHEC lineages (Ogura et al., 2007; Ooka et al., 2007), while tir $_{\text {Sakai }}$ was found mainly in EHEC O157:H7 and its close relatives O55:H7 strains (Garmendia et al., 2005).

Most O55:H7 strains are classified as EPEC (Pupo et al., 1997; Whittam et al., 1993), and the O157:H7 lineage is known to have emerged from an O55:H7-like EPEC ancestor by shifting the $\mathrm{O}$-antigen from $\mathrm{O} 55$ to $\mathrm{O} 157$ and acquiring Shiga toxin (Stx1 and/or Stx2)-converting phages and a large virulence plasmid (pO157) (Wick et al., 2005). Therefore, O55:H7 and O157:H7 strains have a very similar or nearly identical genetic backbone. In fact, similarly to EHEC O157:H7, most O55:H7 strains possess an LEE island encoding $\gamma 1$-intimin and $\mathrm{Tir}_{\text {Sakai }}$ (Garmendia et al., 2005). However, in a recent study (Garmendia et al., 2005), a few O55:H7 strains were found to encode $\mathrm{Tir}_{\mathrm{E} 2348 / 68}$. The aim of this study was to investigate the phylogenetic relationships and genotypic differences between typical O55 : H7 strains expressing $\mathrm{Tir}_{\text {Sakai }}$, atypical O55: H7 strains expressing $\operatorname{Tir}_{\mathrm{E} 2348 / 68}$ and EPEC O55:H6 strains, which are also known to express $\operatorname{Tir}_{\mathrm{E} 2348 / 68}$ (Ogura et al., 2007).

\section{METHODS}

Bacterial strains and preparation of genomic DNA. The bacterial strains used in this study are listed in Table 1. The sequenced EHEC

Table 1. Characteristics of $E$. coli strains used in this study

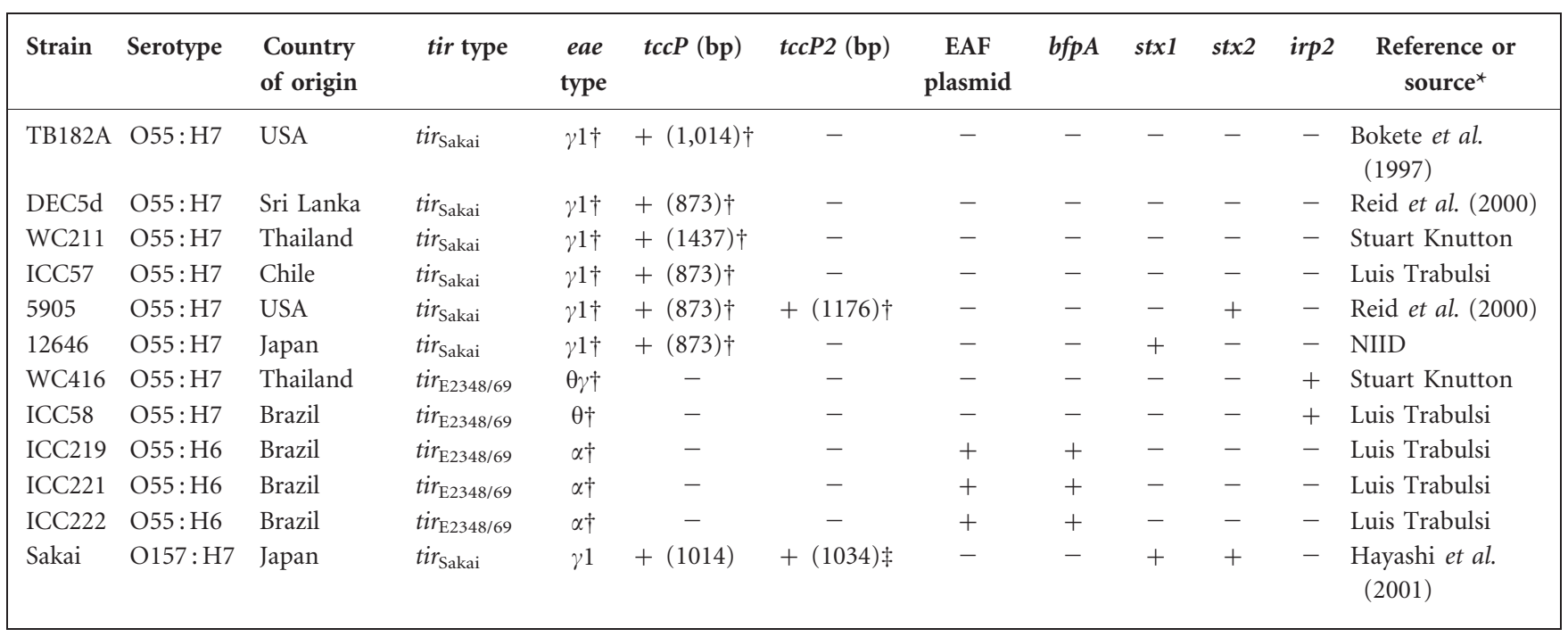

${ }^{\star}$ Stuart Knutton, Institute of Child Health, University of Birmingham, UK; Luis Trabulsi, Laboratório Especial de Microbiologia, Instituto Butantan, São Paulo, Brazil; NIID, National Institute of Infectious Disease, Tokyo, Japan.

$\dagger$ These sequences were determined in this study.

$\ddagger$ Pseudogene. 
O157 : H7 strain RIMD 0509952 (referred to as O157 Sakai) (Hayashi et al., 2001) was used as a reference strain in long PCR and microarray experiments. The bacterial strains were grown to stationary phase at $37{ }^{\circ} \mathrm{C}$ in Luria-Bertani broth. Genomic DNA was purified using the Genomic-tip 100/G and Genomic DNA buffer set (both from Qiagen) according to the manufacturer's instructions.

\section{Subtyping of tir genes and detection of pathotype-associated} genes. Subtyping of tir genes into $t i_{\mathrm{E} 2348 / 68}$ or $t i_{\text {Sakai }}$ was done by PCR using allele-specific primers as described previously (Ogura et al., 2007). Detection of the nine pathotype-associated genes listed in Table 2 was also done by PCR. All PCRs were performed according to the protocols described previously (see references in Table 2).

Sequencing of eae, tccP, tccP2, flic and 15 housekeeping genes. The entire coding regions of the eae, $t c c P, t c c P 2$ and $f l i C$ genes, and internal regions of 15 housekeeping genes ( $\operatorname{arcA}, \operatorname{aroE}, \operatorname{asp} C, c l p X$, cyaA, dnaG, fadD, grpE, icdA, lysP, mdh, mtlD, mutS, rpoS and uidA) were amplified and sequenced for each test strain. Primers used for PCR and sequencing analyses of the eae, tccP, tccP2 and fliC genes are listed in Table 2. PCR amplification was performed with an EX taq PCR kit (Takara Bio) by 30 amplification cycles of denaturation for $30 \mathrm{~s}$ at $96{ }^{\circ} \mathrm{C}$, annealing for $30 \mathrm{~s}$ at $55^{\circ} \mathrm{C}$ and primer extension for $60 \mathrm{~s}$ at $72{ }^{\circ} \mathrm{C}$. Primers and PCR conditions for the analyses of 15 housekeeping genes were set up according to the protocol provided by the multi-locus sequence typing database for pathogenic E. coli (EcMLST: http://shigatox.net/mlst).

Phylogenetic analysis. Multiple alignments of sequences were constructed by using the CLUSTAL w program (Thompson et al., 1994) in the MEGA3 software (Kumar et al., 2004), and then neighbourjoining $(\mathrm{NJ})$ trees were generated by using Tamura-Nei model. A bootstrap test with 1000 replicates was used to estimate the confidence of the branching patterns of the trees.

Microarray analysis. The protocol of comparative genomic hybridization (CGH) analysis using an O157 Sakai oligoDNA microarray has been described previously (Ogura et al., 2006). Briefly, probes were prepared for all protein-coding genes on the O157 Sakai genome (5447 genes in total). Probes were mostly 60-mer in length and two probes were prepared for each gene. Repeated genes with almost identical sequences (542 genes in total) were grouped into 151 repeated gene families, and each family was represented by a single probe. Three micrograms of genomic DNA from the reference strain (O157 Sakai) and each test strain were used to generate Cy5and Cy3-labelled samples, respectively, and cohybridized on a single array. For each test strain, DNA labelling and hybridization were performed twice independently. Fluorescence intensities of the spots were collected using the ArrayVision 8.0 software (Imaging Research). After excluding low-quality signals with lower signal intensity and spotting abnormalities, the signal intensities of each spot were corrected by subtracting the local background, and subjected to the 'presence or absence' determination using the array-based genotyping software GACK (Kim et al., 2002). Finally, the presence or absence of each gene was determined according to the judgments of each spot in two independent hybridizations as described previously (Ogura et al., 2006). Hierarchical cluster analysis was performed using the Cluster 3.0 software (de Hoon et al., 2004), and the result was visualized using the Java TreeView software (Saldanha, 2004).

Long PCR and RFLP analyses. The O55-anigen gene cluster and part of the his operon in the O55:H7 strain TB182A have been sequenced previously (Wang et al., 2002). Based on the sequences of TB182A (accession no. AF461121) and O157 Sakai (BA000007), eight pairs of PCR primers were designed to amplify the $85.6 \mathrm{~kb}$ chromosomal region covering the O55-antigen gene cluster and its flanking regions (Table 2, Fig. 2). Each segment to be amplified
(7.8-19.0 kb) overlapped its neighbours by $21-350 \mathrm{bp}$. Some primers used were previously designed for the whole-genome PCR scanning analysis of $\mathrm{O} 157$ strains (Ohnishi et al., 2002). The protocol for long PCR amplification was also described previously (Ohnishi et al., 2002). For the RFLP analysis of long PCR products, PCR products were purified with a QIAquick PCR purification kit (Qiagen), digested with HaeIII (Takara Bio), and analysed by agarose gel electrophoresis.

Sequence analysis of 055 -antigen gene clusters and their flanking regions. Each long PCR product used for the PCR-RFLP analysis was sheared by sonication and their random shotgun libraries with $1.2-1.7 \mathrm{~kb}$ inserts were constructed using the pTS1 vector (O'Connell et al., 1993). Each clone was sequenced with universal primers T7 and T3 using an ABI PRISM 3100 automated sequencer (Applied Biosystems). Sequence data were assembled by the Sequencher software, ver. 4.2.2 (Gene Codes). The open reading frame finder program in the in silico MolecularCloning Genomic Edition, version 1.4.6 (in silico biology, Kanagawa, Japan) was used for the initial gene finding and annotation. Final annotation was manually done according to the results of database searches using the BLASTP program (Altschul et al., 1997). Sequence alignments and comparisons were performed by the Sequencher and the CLUSTAL $\mathrm{W}$ programs.

\section{RESULTS}

\section{Subtyping of Tir, TccP/P2 and intimin}

Of the eight O55:H7 strains examined (Table 1), six (TB182A, DEC5d, WC211, ICC57, 5905 and 12646) possessed tir $_{\text {Sakai }}$, while two (WC416 and ICC58) possessed tir $_{\mathrm{E} 2348 / 68}$ (Garmendia et al., 2005). All the O55:H7 strains with $\mathrm{Tir}_{\text {Sakai }}$ were $t c c P$ positive (strain 5905 was also $t c c P 2$ positive) and possessed the eae gene (2805 bp) encoding $\gamma 1$ subclass intimin (Int- $\gamma 1$ ), which was almost identical to the eae gene of O157 Sakai, with at most three nucleotide differences. In contrast, the two O55:H7 strains with $\operatorname{Tir}_{\mathrm{E} 2348 / 68}$ were $t c c P$ and $t c c P 2$ negative and possessed an eae gene $(2808 \mathrm{bp})$ encoding the $\theta$ subclass intimin (Int- $\theta$ ), which was almost identical to the eae gene of EHEC O111 : H8 strain DEC8b (accession no. AF449420), with a single nucleotide difference. Although the intimin of strain ICC58 had been classified as Int- $\gamma$ in several previous studies where PCR-based intimin-typing systems were employed, the sequence analysis clearly indicated that strain ICC58 encodes Int $\theta$. On the basis of their virulence gene combination, the eight $\mathrm{O} 55$ : $\mathrm{H} 7$ strains examined here were divided into two subgroups referred to as $\mathrm{O} 55: \mathrm{H} 7 / \mathrm{Int}-\gamma 1$ and $\mathrm{O} 55: \mathrm{H} 7 /$ Int $-\theta$, respectively. The three O55: H6 strains with $\operatorname{Tir}_{\mathrm{E} 2348 / 68}$ were $t c c P$ and $t c c P 2$ negative, and possessed the eae gene (2820 bp) encoding the $\alpha$ subclass intimin (Int$\alpha$ ), which was almost identical to the eae gene of EPEC O127:H6 strain E2348/69 (accession no. AF022236), with three nucleotide differences.

\section{Other virulence gene profiles}

The presence of other virulence genes known to be associated with EPEC, EHEC or enteroaggregative E. coli 
Table 2. Primers used in this study

\begin{tabular}{|c|c|c|c|c|}
\hline Locus & & Primer & Sequence & Reference \\
\hline \multicolumn{5}{|l|}{ PCR and sequencing: } \\
\hline \multirow{2}{*}{\multicolumn{2}{|c|}{$\mathrm{N}$-terminal part of eae }} & cesT-F9 & TCAGGGAATAACATTAGAAA & Hyma et al. (2005) \\
\hline & & eae-R3 & TCTTGTGCGCTTTGGCTT & \\
\hline \multirow{2}{*}{\multicolumn{2}{|c|}{ C-terminal part of eae }} & eae-F1 & ACTCCGATTCCTCTGGTGAC & Hyma et al. (2005) \\
\hline & & escD-R1 & GTATCAACATCTCCCGCCCA & \\
\hline \multirow{2}{*}{\multicolumn{2}{|c|}{$t c c P$}} & tccP-SF & GATGAGTATTGCATCGAGTGTC & Ogura et al. (2007) \\
\hline & & tccP-SR & CGGTAACTGTCAGGTCAGAGC & \\
\hline \multirow{2}{*}{\multicolumn{2}{|c|}{$\operatorname{tccP} 2$}} & tccP2-Sfa & AAACGGATAAATAAGACTATCC & Ogura et al. (2007) \\
\hline & & tccP2-SRa & AATAACCGGTAACTGTCAGGTC & \\
\hline \multirow{2}{*}{\multicolumn{2}{|c|}{ fliC }} & 1575 & GGGTGGAAACCCAATACG & Wang et al. (2000) \\
\hline & & 1576 & GCGCATCAGGCAATTTGG & \\
\hline \multicolumn{5}{|l|}{ (Internal sequencing) } \\
\hline \multicolumn{2}{|l|}{$\mathrm{N}$-terminal part of eae } & SK1 & CCCGAATTCGGCACAAGCATAAGC & Karch et al. (1993) \\
\hline \multicolumn{2}{|l|}{ C-terminal part of eae (Int- $\alpha)$} & LP2 & CCCGAATTCTTATTTTACACAAGTGGC & Schmidt et al. (1993) \\
\hline \multicolumn{2}{|l|}{ C-terminal part of eae (Int- $\gamma)$} & LP3 & CCCGAATTCTTATTCTACACAAACCGC & Schmidt et al. (1993) \\
\hline \multirow{2}{*}{\multicolumn{2}{|c|}{$\begin{array}{l}f l i C \\
\text { Subtyping of tir genes: }\end{array}$}} & 1806 & GCTGCAACGGTAAGTGAT & Wang et al. (2000) \\
\hline & & & & \\
\hline \multirow{2}{*}{\multicolumn{2}{|c|}{ E2348/69-like tir }} & $\operatorname{tirY} 474 \mathrm{~F}$ & CATATTTATGATGAGGTCGCTC & Ogura et al. (2007) \\
\hline & & tir-R & TAAAAGTTCAGATCTTGATGACAT & \\
\hline \multirow{2}{*}{\multicolumn{2}{|c|}{ Sakai-like tir }} & $\operatorname{tirS478\mathrm {F}}$ & TCTGTTCAGAATATGGGGAATA & Ogura et al. (2007) \\
\hline & & tir-R & TAAAAGTTCAGATCTTGATGACAT & \\
\hline \multicolumn{5}{|c|}{ Detection of pathotype-associated genes: } \\
\hline \multirow{2}{*}{\multicolumn{2}{|c|}{$t c c P$}} & tccP-F & ATGATTAACAATGTTTCTTCACTT & Ogura et al. (2007) \\
\hline & & univ-tccP-R & TCACGAGCGCTTAGATGTATTAAT & \\
\hline \multirow{2}{*}{\multicolumn{2}{|c|}{ tccP2 }} & tccP2 F & ATGATAAATAGCATTAATTCTTT & Ogura et al. (2007) \\
\hline & & univ-tccP-R & TCACGAGCGCTTAGATGTATTAAT & \\
\hline \multirow{2}{*}{\multicolumn{2}{|c|}{ EAF plasmid specific region }} & EAF1 & CAGGGTAAAAGAAAGATGATAA & Franke et al. (1994) \\
\hline & & EAF25 & TATGGGGACCATGTATTATCA & \\
\hline \multirow{2}{*}{\multicolumn{2}{|c|}{$b f p A$}} & EP1 & AATGGTGCTTGCGCTTGCTGC & Gunzburg et al. (1995) \\
\hline & & EP2 & GCCGCTTTATCCAACCTGGTA & \\
\hline \multirow{2}{*}{\multicolumn{2}{|c|}{ stx 1}} & LP30 & CAGTTAATGTGGTGGCGAAGG & Cebula et al. (1995) \\
\hline & & LP31 & CACCAGACAATGTAACCGCTG & \\
\hline \multirow{2}{*}{\multicolumn{2}{|c|}{ stx 2}} & LP43 & ATCCTATTCCCGGGAGTTTACG & Cebula et al. (1995) \\
\hline & & LP44 & GCGTCATCGTATACACAGGAGC & \\
\hline $\operatorname{aggR}$ & & $\operatorname{aggR}(\mathrm{F})$ & CTAATTGTACAATCGATGTA & Nataro et al. (1994) \\
\hline & & $\operatorname{aggR}(\mathrm{R})$ & ATGAAGTAATTCTTGAAT & \\
\hline ast $A$ & & EAST11a & CCATCAACACAGTATATCCGA & Yamamoto \& Nakazawa (1997) \\
\hline & & EAST11b & GGTCGCGAGTGACGGCTTTGT & \\
\hline $\operatorname{irp2}$ & & $\operatorname{irp} 2(\mathrm{FP})$ & AAGGATTCGCTGTTACCGGAC & Schubert et al. (1998) \\
\hline & & $\operatorname{irp} 2(\mathrm{RP})$ & TCGTCGGGCAGCGTTTCTTCT & \\
\hline Long PCR & Fragment size (bp) & & & \\
\hline Segment 1 & 8534 & $208 \mathrm{FrF}$ & GATAAAACTCGGGCTCGCCGTG & This study \\
\hline & & O55re-3R & AGCAGGGCGATGACTTCATCCA & \\
\hline Segment 2 & $9023[9027 \dagger]$ & O55re-2F & ССАССТСТТАТССТСАССТGСТ & This study \\
\hline & & O55re-2R & TCCGGTACTGGCTATGTAGGCT & \\
\hline Segment 3 & $18482[18960 \dagger]$ & O55re-1F & CATAGTCGGTTGGAGTGGCGAT & This study \\
\hline & & O55re-1R & TTGCCGGAACGGAGAGAGTAGA & \\
\hline Segment 4 & 10336 & O55re-0F & GCCGTTTCAAGTAGTCGGGTTC & This study \\
\hline & & O55re-0R & TCCTGCTGCCCAAACACAACAC & \\
\hline Segment 5 & 13745 & O55re-AF & TGGATAGAGTTTCGACTGCGCC & This study \\
\hline & & $213 \mathrm{R}$ & CTTTCCCTTCCAGCCGTTCGTT & Ohnishi et al. (2002) \\
\hline Segment 6 & 8813 & $213 \mathrm{~F}$ & TCCGCTCGTTTACCTTTAGCGC & Ohnishi et al. (2002) \\
\hline & & $214 \mathrm{R}$ & TAAGGGTAAAACGACTGGCCCG & \\
\hline
\end{tabular}


Table 2. cont.

\begin{tabular}{|lllll|}
\hline Locus & & Primer & \multicolumn{1}{c|}{ Sequence } & Reference \\
\hline Segment 7 & 7780 & $214 \mathrm{~F}$ & CCGGGCCAGTCGTTTTACCCT & Ohnishi et al. (2002) \\
& & $215 \mathrm{FrR}$ & TGCTTGAGACCAACGCGACCAT & This study \\
Segment 8 & \multirow{2}{*}{9965} & $215 \mathrm{~F}$ & ACCGAAGGCACCATTAAGGCTG & Ohnishi et al. (2002) \\
& & $216 \mathrm{R}$ & ATTTCCCGGCACAGCGTCAGG & \\
& & & & \\
& & & &
\end{tabular}

${ }^{\star}$ Expected sizes of PCR products in O157 Sakai.

$\dagger$ Expected sizes of PCR products in O55: H7 strain TB182A.

(EAEC) was examined in each of the 055 strains by PCR (Table 1). The O55: H7/Int- $\theta$ and $055: H 7 /$ Int $-\gamma 1$ strains did not possess the EPEC adherence factor (EAF) plasmid or the $b f p A$ gene encoding a subunit of bundle-forming pili. Therefore, they were categorized as atypical EPEC (Trabulsi et al., 2002), except for O55:H7/Int- $\gamma 1$ strains 5905 and 12646, which were stx 2 or stx 1 positive and thus categorized as EHEC. The O55:H6 strains were typical EPEC as they harbour the EAF plasmid and carry the $b f p A$ gene (Trabulsi et al., 2002). Of note is the fact that the O55: H7/Int- $\theta$ strains were found to contain the irp2 gene, which encodes an iron-repressible high-molecular-weight protein HMWP2, one of the virulence gene markers of EAEC (Schubert et al., 1998). However, other EAEC markers, $\operatorname{aggR}$ (encoding a regulator for the expression of aggregative adherence fimbriae) and astA (encoding heatstable enterotoxin EAST1), were both negative in the O55 : H7/Int- $\theta$ strains (data not shown).

\section{Comparison of fliC $_{\mathrm{H} 7}$ sequences}

The $\mathrm{fliC}$ genes encoding $\mathrm{H} 7$ antigen are known to exhibit sequence variations, and 10 distinct subtypes (H7-1 to H710) have been described (Wang et al., 2000). All the fli $_{\mathrm{H} 7}$ sequences of the $055: \mathrm{H} / / \mathrm{Int}-\gamma 1$ strains were identical to the $\mathrm{H} 7-5$ sequence of $\mathrm{O} 157$ : $\mathrm{H} 7$ strains. In contrast, those of the $\mathrm{O} 55: \mathrm{H} 7 /$ Int $-\theta$ strains were almost identical to the H7-7 sequence of an O19ab:H7 strain, with one or two nucleotide differences. Eight nucleotide differences exist between the DNA sequences of H7-5 and H7-7 (Wang et al., 2000).

\section{Phylogenetic relationship of 055 strains}

We analysed the phylogenetic relationship of the $11 \mathrm{O} 55$ strains ( $\operatorname{cix}$ O55: H7/Int- $\gamma$ 1, two O55:H7/Int- $\theta$ and three O55:H6/Int- $\alpha$ ) based on the concatenated nucleotide sequences (7395 bp) of 15 housekeeping genes. As shown in Fig. 1, the $\mathrm{O} 55$ strains formed three distinct clusters. All the $\mathrm{O} 55: \mathrm{H} 7 /$ Int- $\gamma 1$ strains were tightly associated with the EHEC O157:H7 lineage, while the two O55:H7/Int- $\theta$ strains and the three $\mathrm{O} 55: \mathrm{H} 6 / \mathrm{Int}-\alpha$ strains formed distinct clusters. The nucleotide sequence identity of the housekeeping genes within each O55 lineage was $>99.9 \%$, but those between the three lineages ranged from 97.2 to $97.6 \%$.

\section{Differences in gene content between the three O55 lineages}

To examine the genotypic differences among O55 strains, we analysed the gene contents of eight $\mathrm{O} 55$ strains from the three lineages (three O55:H7/Int- $\gamma 1$, two O55:H7/Int- $\theta$ and three O55:H6/Int- $\alpha$ strains) by using the O157 Sakai oligoDNA microarray (Fig. 2). Most O157 Sakai genes are represented by two probes on this array (Ogura et al., 2006). The probes were divided into two groups by their homologies to the K-12 genome sequences: probes sharing $\geqslant 90 \%$ identity and probes sharing $<90 \%$ identity. Genes were then classified into 'conserved in K-12' genes (both probes share $\geqslant 90 \%$ identity), 'partly conserved in K-12' genes (one probe shares $\geqslant 90 \%$ identity but the other $<90 \%$ identity), or 'Sakai-specific' genes (both probes share $<90 \%$ identity). Genes with more than one copy in the O157 Sakai genome (referred to as repeated genes) were analysed separately from singleton genes (see Supplementary Table S1, available with the online version of this paper).

Analysis of singleton genes and a hierarchical clustering tree are shown in Fig. 2 (for details, see Table S1). The O55 strains examined were divided into three clusters according

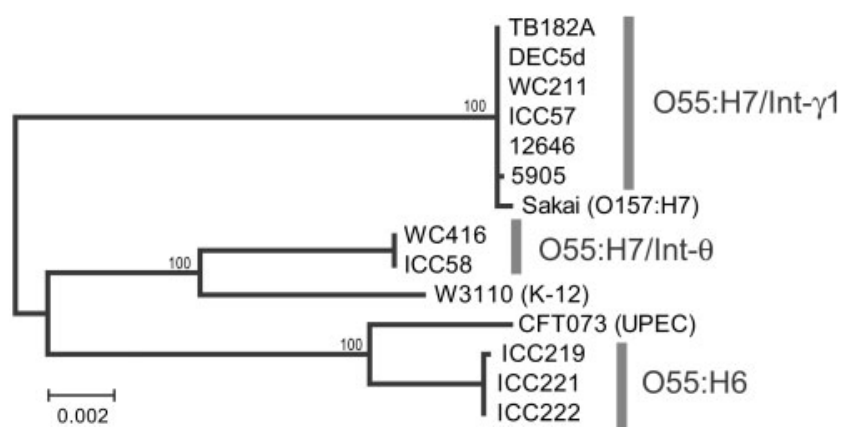

Fig. 1. Phylogenetic analysis of 055 strains based on the sequences of 15 housekeeping genes. The phylogenetic tree was constructed based on the concatenated sequences of 15 housekeeping genes by using the $\mathrm{NJ}$ algorithm. Bootstrap analysis was performed with 1000 replicates. The sequence data of $E$. coli K-12 strain W3110 and uropathogenic E. coli (UPEC) strain CFT073 were taken from the GenBank database (accession nos AP009048 and AE014075, respectively). 


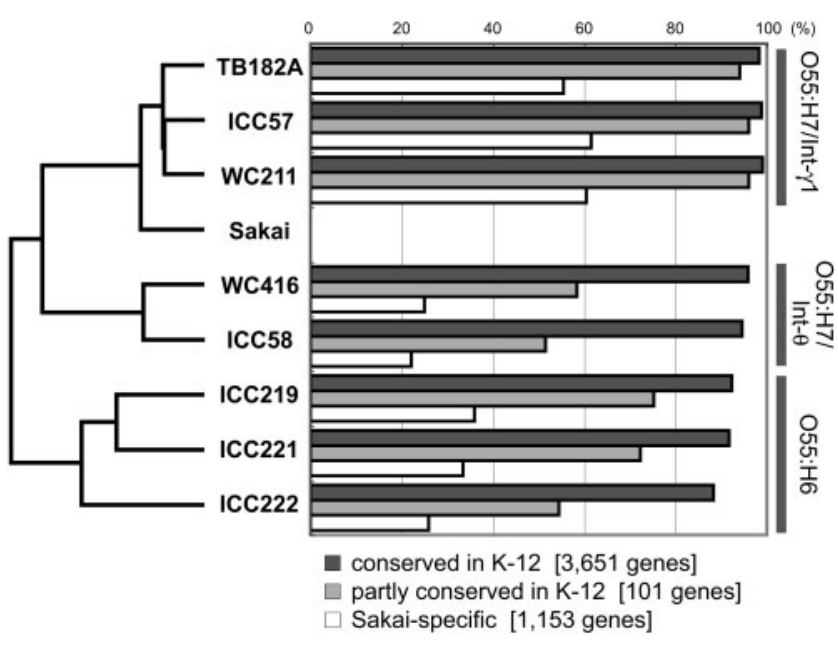

Fig. 2. Summary of the $\mathrm{CGH}$ analyses of $\mathrm{O} 55$ strains using an O157 Sakai oligoDNA microarray. The hierarchical clustering tree was obtained from the $\mathrm{CGH}$ data of 4905 singleton genes. The O157 Sakai singleton genes were categorized into three groups, 'conserved in K-12', 'partly conserved in K-12' and 'Sakai-specific' genes, and gene conservation (\%) in each category was analysed for each test strain. For the data of repeated genes, see Supplementary Table S1.

to their gene contents. The clustering pattern was consistent with their phylogenies; the O55:H7/Int- $\gamma 1$ group was closely related to O157 Sakai.

Among the 49050157 Sakai singleton genes, 'Conserved in K-12' genes (3651 genes) were highly conserved in the O55:H7/Int- $\gamma 1$ strains (98.3-99.1\%) and also in other O55 strains, although to slightly lesser extents (88.3-95.9\% but most $>90 \%)$. 'Partly conserved in K-12' genes (101 genes) were also highly conserved in the O55:H7/Int- $\gamma 1$ strains (94.1-96.0\%), but intermediately in the other strains (51.5-75.2\%). 'Sakai-specific' genes (1153 genes) exhibited moderate conservation in the O55:H7/Int- $\gamma 1$ strains (55.4-61.5\%), but were very poorly conserved in the O55:H7/Int- $\theta \quad(22.1-25.0 \%)$ and O55:H6 (25.9$35.9 \%)$ strains. 'Sakai-specific' genes that were found to be missing in the $\mathrm{O} 55: \mathrm{H} 7 / \mathrm{Int}-\gamma 1$ strains were mainly on prophage and prophage-like elements (see Supplementary Fig. S1, available with the online version of this paper). In the other $\mathrm{O} 55$ strains, the missing genes were dispersed on the genome. These results indicated that $\mathrm{O} 55: \mathrm{H} 7 / \mathrm{Int}-\theta$ strains were very different from the $\mathrm{O} 55: \mathrm{H} 7 / \mathrm{Int}-\gamma 1$ group also with respect to their gene repertoire.

\section{PCR-RFLP analysis of 055-antigen gene clusters and their flanking regions}

The results described above clearly indicated that $\mathrm{O} 55: \mathrm{H} 7 /$ Int- $\gamma 1$, O55:H7/Int- $\theta$ and O55:H6 strains belonged to distinct E. coli lineages, but expressed the same O55 antigen. In order to understand the genetic mechanism underlying the emergence of $\mathrm{O} 55$ strains in the three different E. coli lineages, we compared the O-antigen gene clusters of the three $\mathrm{O} 55$ lineages. We first performed a PCR-RFLP analysis of eight chromosomal segments covering the $85.6 \mathrm{~kb}$ region where the $\mathrm{O}$-antigen gene cluster is located (Fig. 3). Segment 3 encoding most of the O55 gene cluster and segment 4 encoding half of the colanic acid biosynthesis gene cluster exhibited an identical RFLP pattern in all the O55 strains. In contrast, segments 1, 2, 7 and 8 exhibited different patterns between the three lineages, but an almost identical pattern within a lineage, with only few minor variations. Segments 5 and 6 exhibited an identical pattern in all the O55: H7/Int- $\gamma 1$ and O55: H6 strains with one exception (segment 6 of WC211), but those of $\mathrm{O} 55: \mathrm{H} 7 / \mathrm{Int}-\theta$ strains were slightly different from the others. These results suggest that the three O55 lineages share an identical or nearly identical sequence of the O55 and part of the colanic acid biosynthesis gene clusters, and that the left and right junctions between the lineagespecific and shared sequences are located in segment 2 and in segments 5 or 7 , respectively.

\section{Sequence analysis of the 055-antigen gene clusters and their flanking regions}

To gain more information about the genetic similarity of the three O55-antigen gene clusters and junction points between the lineage-specific and shared sequences, we sequenced the $65 \mathrm{~kb}$ chromosome regions encompassing segments 2 to 7 of a representative strain of each lineage (TB182A for O55:H7/Int- $\gamma 1$, WC416 for O55:H7/Int- $\theta$ and ICC219 for O55:H6). The sequence of the O55 gene cluster of TB182A was identical to that previously reported (Wang et al., 2002).

Overall gene organization. The overall gene organization in the sequenced region was almost identical between the three strains, with a few exceptions in WC416 (Fig. 4), which lacked a 745 bp fragment encoding two small genes (corresponding to ECs2869 and 2870 of O157 Sakai), but contained a 684 bp fragment encoding the yegJ gene. The gene organization of the yegH-yegL region of WC416 was thus identical to that of E. coli K-12 strain WC3110 (data not shown). This may be linked to the relatively close phylogenetic relationship between H7/Int- $\theta$ strains and K12 (Fig. 1).

Pairwise sequence comparison. Sequence similarities between the three strains were analysed by pairwise comparisons. Consistent with the results of PCR-RFLP analyses, nearly identical sequences were found in the O55 and part of the colanic acid biosynthesis gene clusters, which were located between lineage-specific sequences in each strain (Fig. 4).

Comparison of TB182A and WC416 defined the left and right junctions of the lineage-specific and shared sequences within hisI and $w z c$, respectively. The $42.3 \mathrm{~kb}$ region from 


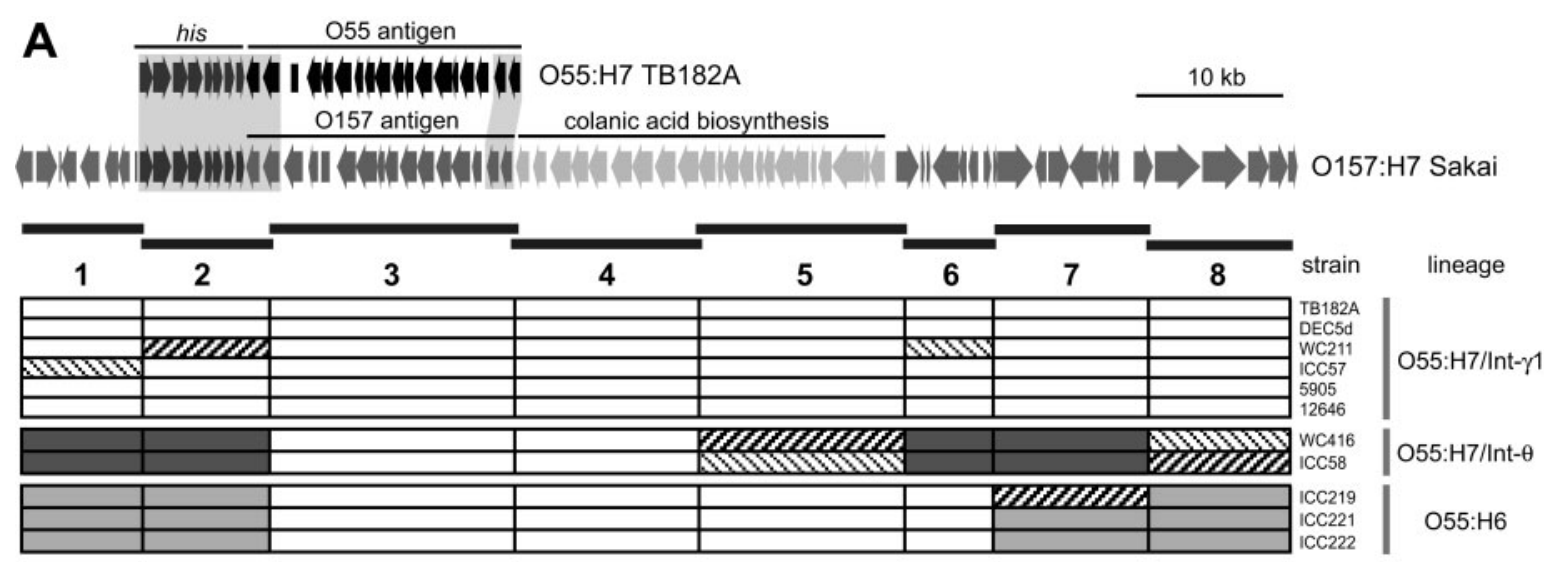

B
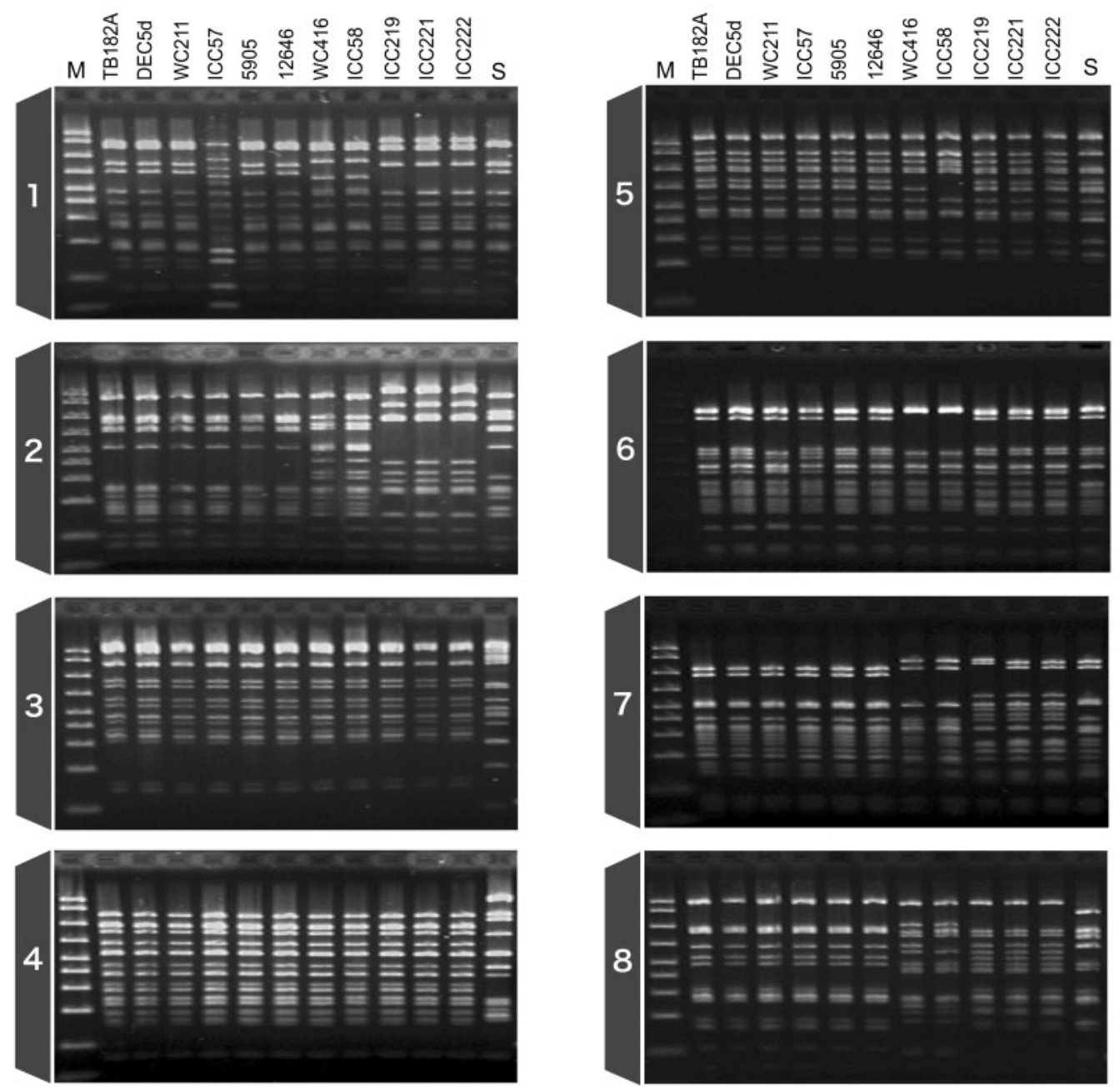

Fig. 3. PCR-RFLP analyses of the O55-antigen gene clusters and their flanking regions. (A) The upper panel is a schematic representation of the O-antigen gene clusters and their flanking regions in EHEC O157 Sakai and O55:H7 strain TB182A. Segments $1-8$, each amplified by long PCR, are indicated by heavy lines. The lower panel shows the summary of PCR-RFLP of the 11055 strains. Segments exhibiting different RFLP patterns are indicated by boxes with different shading and patterns. (B) PCR-RFLP patterns of each segment. PCR products were digested with Haell. Lanes M, AmpliSize Molecular Ruler (502000 bp ladder) (Bio-Rad); lanes S, O157 Sakai. 


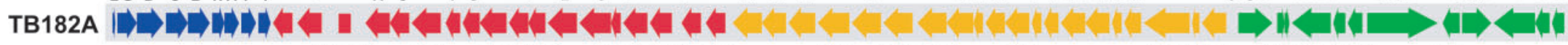
$H$ repeat gnd wzx wbgN gmm wbgM gne wzxC cpsG cpsB gmd

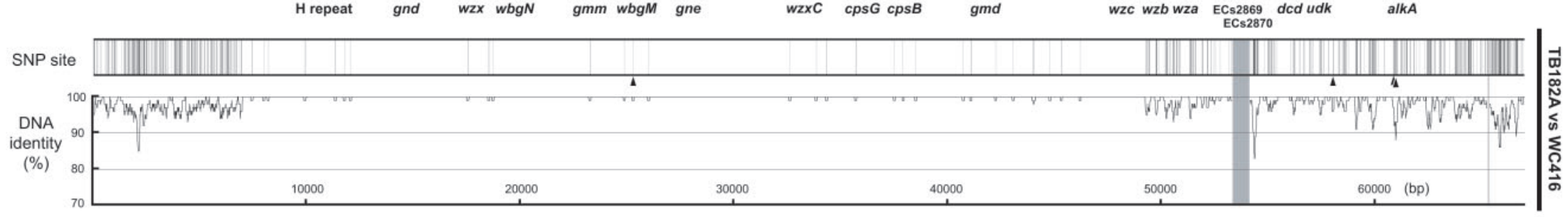

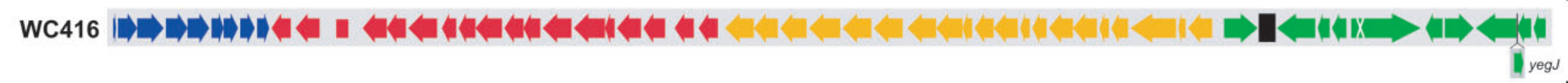

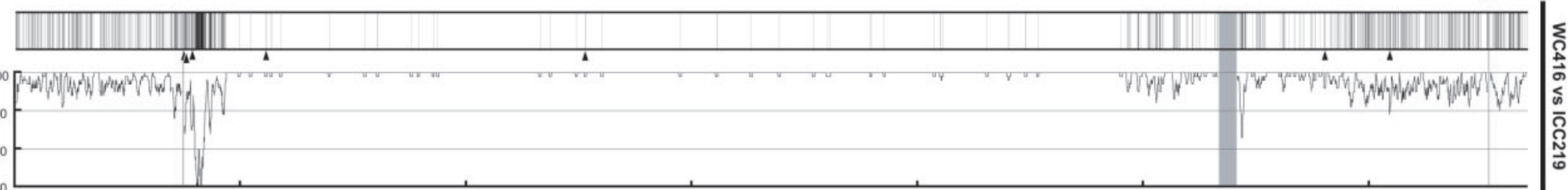

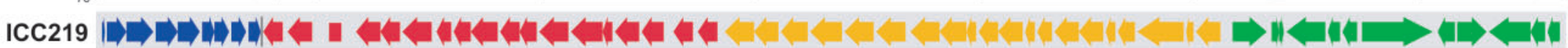

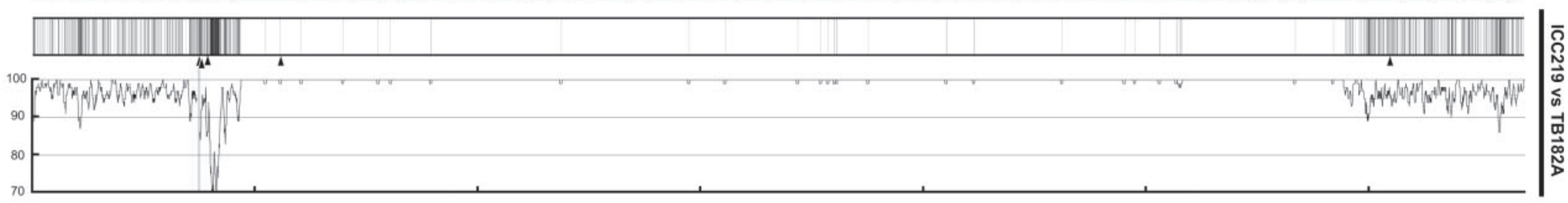

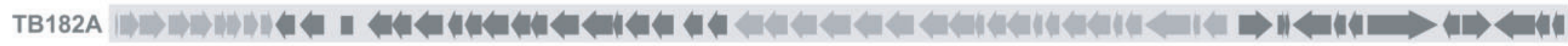

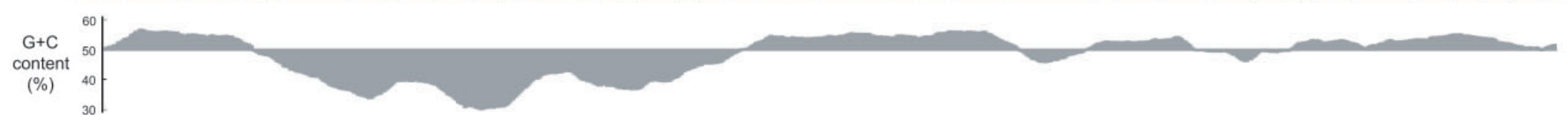

Fig. 4. Pairwise sequence comparisons of the $\mathrm{O} 55$ gene clusters and their flanking regions. The genetic organization of the O55-antigen gene clusters and their flanking regions in O55 strains TB182A, WC416 and ICC219 is shown; black regions (ECs2869-70 region in WC416 and his/-wzz intergenic region in ICC219) indicate gaps. Locations of SNPs, indicated by vertical lines (upper panel), and levels of \% DNA sequence identity calculated with a $100 \mathrm{bp}$ sliding window and a step size of $10 \mathrm{bp}$ (lower panel) are shown for each pairwise comparison. Small indels (<9 bp) are indicated by arrowheads. The $\mathrm{G}+\mathrm{C}$ content of TB182A is shown at the bottom (calculated with a $1 \mathrm{~kb}$ sliding window and a step size of $100 \mathrm{bp}$ ). 
hisI to $w z c$ had only 29 single nucleotide polymorphisms (SNPs) and a $6 \mathrm{bp}$ indel. The nucleotide sequence identities of lineage-specific sequences were $96.8 \%$ on the left hand and $97.7 \%$ on the right hand, showing a similar level of sequence diversity as that observed in the 15 housekeeping genes $(97.5 \%)$. Between WC416 and ICC219, the left and right junctions were localized within $u g d$ and $w z c$, respectively. The $40.0 \mathrm{~kb}$ region from ugd to $w z c$ had only 33 SNPs and a 1 bp and a 6 bp indel. The identities of lineage-specific sequences were $95.2 \%$ (left) and $97.2 \%$ (right). Similarly, between ICC219 and TB182A, the left and right junctions were within ugd and $y e g E$, the $49.6 \mathrm{~kb}$ region from $u g d$ to $y e g E$ had 27 SNPs and a $1 \mathrm{bp}$ indel, and the identities of lineage-specific sequences were $94.9 \%$ (left) and $96.0 \%$ (right). It is noteworthy that the $w z z$ gene and its upstream region of O55:H6 strain ICC219 had a highly divergent sequence compared with the others.

Evolutionary relationship of flanking regions. To evaluate the evolutionary relationships of the three O55 lineage specific sequences flanking the O55-antigen and colanic acid biosynthesis gene clusters, concatenated sequences of the hisGDCBHA genes (left hand), and of the alkA and yegDIKL genes (right hand) (5667 and $5583 \mathrm{bp}$, respectively) were compared. Both sequences generated phylogenetic trees similar to that of housekeeping genes (Fig. 5). This result indicated that both flanking regions were inherited in each lineage through their evolution. The phylogenetic relationship of the colonic acid biosynthesis genes and their homologues in other E. coli strains was also analysed by using the concatenated sequences of the wcaA$F$ genes (3897 bp) and the $w c a K-M$ genes (5061 bp). In both cases, the sequences from three O55 lineages form a single cluster, but showed no close relationship to any other E. coli sequences currently available (data not shown).

\section{DISCUSSION}

In this study, we analysed the phylogenetic and genotypic differences between typical EPEC O55: H7 strains possessing $t i r_{\text {Sakai }}$ and atypical EPEC O55:H7 strains possessing $\operatorname{tir}_{\mathrm{E} 2348 / 68}$. The data clearly indicated that atypical O55:H7 strains belong to an E. coli lineage distinct from typical strains that are close relatives of EHEC O157:H7. While the typical $\mathrm{O} 55: \mathrm{H} 7$ strains were categorized as atypical EPEC and encoded Int $-\gamma 1$ (O55:H7/Int $-\gamma 1)$ and TccP, atypical $\mathrm{O} 55: \mathrm{H} 7$ strains were also categorized as atypical EPEC but encoded Int $-\theta$ (O55: H7/Int- $\theta)$ and lacked TccP or TccP2. Although Int $\theta$ was originally identified in $E$. coli O111 strains (Tarr \& Whittam, 2002), it has been found in other E. coli serotypes including $\mathrm{O} 5: \mathrm{H} 11, \mathrm{O} 35: \mathrm{H} 25$, O76:H7, O84:H25 and O103:H2 (Ramachandran et al., 2003). Interestingly, an O55: H7 strain with Int- $\theta$ (named LTO55-43) has been described before (Lacher et al., 2006) and the strain information is available at the STEC centre Isolate Database (http://www.shigatox.net/cgi-bin/stec/ index). Extracting data from this resource has shown that the sequences of 15 housekeeping genes of this strain are identical to those of the two O55:H7/Int- $\theta$ strains we analysed in this study. Strains ICC58 and LTO55-43 were isolated in Brazil but WC416 in Thailand (Table 1), suggesting the global distribution of the O55:H7/Int- $\theta$ clonal group.

An intriguing genotype characteristic of the $\mathrm{O} 55: \mathrm{H} 7 / \mathrm{Int}-\theta$ strains was the presence of the irp2 gene, which is located in an operon specifying the yersiniabactin-mediated ironuptake system. This operon was originally identified on the high-pathogenicity island of Yersinia pestis (Fetherston et al., 1995). Schubert et al. (1998) reported that $93 \%$ of 60 EAEC isolates were $i r p 2$ positive. The authors reported that the gene was detected in a few EPEC but not in EHEC strains. However, more recently, Girardeau et al. (2005) reported that $34 \%$ of the strains belonging to the EHEC 2

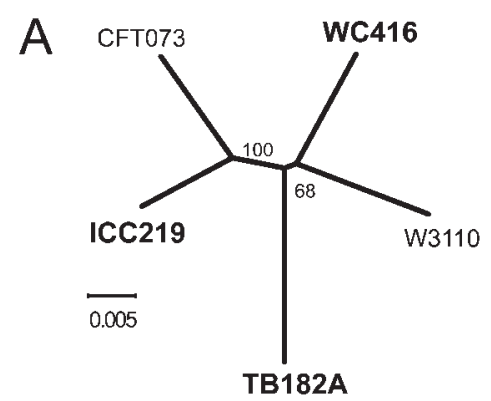

hisG - hisA

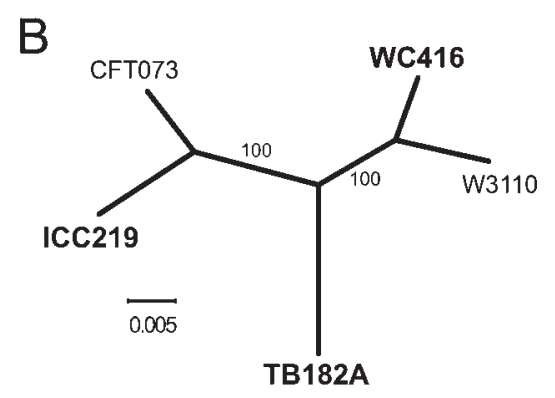

alkA - yegL

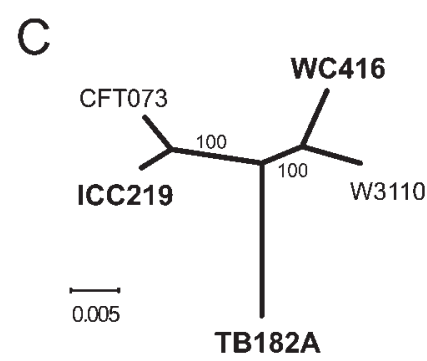

15 housekeeping loci

Fig. 5. Phylogenetic analyses of the $\mathrm{O} 55$ gene cluster-flanking regions and housekeeping genes. The phylogenetic trees were constructed based on the sequences of his GDCBHA genes (A), alkA and yegDIKL genes (B), and 15 housekeeping genes (C) by using the $\mathrm{NJ}$ algorithm. Bootstrap analysis was performed with 1000 replicates. Analyses using the UPGMA algorithm also generated similar phylogenetic trees (date not shown). 
clonal group also harboured this island. The irp2 gene could be used as an additional genetic marker to distinguish $\mathrm{O} 55: \mathrm{H} 7 /$ Int $-\theta$ strains from $\mathrm{O} 55: \mathrm{H} 7 /$ Int $-\gamma 1$ strains.

Horizontal gene transfer (HGT) is widely regarded as a major genetic mechanism to generate variations in $\mathrm{O}$ serotypes between and within bacterial species, although the mechanism is not well understood. Most evidence for the horizontal transfer of $\mathrm{O}$-antigen gene clusters has been obtained by comparing their sequences between closely related strains with different serotypes or phylogenetically unrelated strains with the same serotype. An excellent example of the former approach is provided by analyses of Vibrio cholerae O1 and O139 Bengal. Several studies have shown that a $V$. cholerae $\mathrm{O} 1$ progenitor had acquired a new $\mathrm{O}$-antigen gene cluster and emerged as O139 Bengal (Mooi \& Bik, 1997; Stroeher \& Manning, 1997; Stroeher et al., 1998). In this O-antigen shift, a $22 \mathrm{~kb}$ region for the O1antigen gene cluster was replaced by a $35 \mathrm{~kb}$ fragment encoding the $\mathrm{O} 139$-antigen gene cluster. The $\mathrm{O}$-antigen shift from EPEC O55:H7 to EHEC O157:H7 appears to be the result of recombination within the galF gene (Wang et al., 2002), but more details remained to be clarified.

The latter type of studies of $\mathrm{O}$-antigen evolution mainly involved sequence comparisons of $\mathrm{O}$-antigen gene clusters between strains with a common antigenicity but belonging to different species. The data from a comparison of E. coli $\mathrm{O} 9 \mathrm{a}$ and Klebsiella $\mathrm{O} 3$ suggested that about two-thirds of the $\mathrm{O}$-antigen gene cluster of $E$. coli O9a was derived from Klebsiella O3 (Sugiyama et al., 1998). It has also been shown that the gene organization of the $\mathrm{O}$-antigen gene cluster of $E$. coli $\mathrm{O} 98$ and Yersinia kristensenii $\mathrm{O} 11$ is identical and the gene cluster of $Y$. kristensenii is flanked by remnants of insertion sequences (ISs), thus suggesting the IS-mediated transfer of the $\mathrm{O}$-antigen gene cluster from E. coli $\mathrm{O} 98$ to $Y$. kristensenii O11 (Cunneen \& Reeves, 2007). These and other studies have provided substantial evidence for the dissemination of O-antigen biosynthesis genes between species through HGT, but horizontally transferred sequences and/or their junctions have rarely been well defined.

The present sequence comparison of the O55-antigen gene clusters and their flanking regions between the three different $E$. coli lineages provided strong evidence that the $\mathrm{O}$-antigen shifts have taken place via the horizontal transfer of large fragments $(>40 \mathrm{~kb})$ encoding not only the Oantigen gene cluster but also neighbouring colanic acid biosynthesis genes (Fig. 4). The possible recombination points on the chromosomes have also been identified (Fig. 4). Bacteriophage-mediated general transduction or plasmid-mediated conjugation appears to have been involved in the horizontal transfer of such large chromosomal fragments.

We cannot determine whether these fragments were transferred directly or indirectly to the three O55 lineages from a common ancestor. But, based on the sequence variations of 15 housekeeping genes, it can be estimated that three lineages were separated from a common ancestor $4.7-5.7 \times 10^{6}$ years ago if a uniform rate of synonymous substitution proposed for E. coli and Salmonella enterica $\left(4.7 \times 10^{-9}\right.$ per site per year) is applied (Lawrence \& Ochman, 1998). In contrast, the sequence variations of the $40 \mathrm{~kb}$ region shared by the different lineages imply that the three $\mathrm{O} 55$ gene clusters were separated $0.9-1.4 \times 10^{5}$ years ago. Thus, each lineage acquired the $\mathrm{O} 55$ gene cluster relatively recently.

Of interest is the fact that possible recombination points are not the same between the three lineages. No repetitive sequences were found around the recombination points, such as IS elements and Chi octamer sequences (GCTGGTGG), which may be involved in the transfer and/or recombination of incoming foreign DNA (Dixon \& Kowalczykowski, 1993). Although an H-repeat is present in the $\mathrm{O} 55$ gene cluster, it is not located at the junctions (Fig. 4). Thus, in either lineage, the replacement of the incoming fragment seems to have been achieved by homologous recombination between the allelic regions. To better understand the genetic mechanism(s) generating a wide variety of $\mathrm{O}$-serotypes, we need to know more about whether transfer of such large fragments is involved in Oantigen shifts in other E. coli lineages and also in other bacterial species.

Although the O55-antigen biosynthesis genes of the three lineages were almost identical, the DNA sequence of the $w z z$ gene of ICC219 was significantly divergent from its counterparts in the other two lineages. The encoded protein showed only $89.3 \%$ amino-acid sequence identity to those of strains TB182A and WC416. The Wzz protein is involved in the chain length determination of O-antigen. Guo et al. (2005), who analysed two E. coli strains of serotype O86 that contained Wzz proteins with divergent sequences ( $90 \%$ identical in amino-acid sequence), reported that the difference in Wzz proteins strongly affects the length of $\mathrm{O}$-antigen chains. The length of the $\mathrm{O}$ antigen chain affects various properties of Gram-negative bacteria, including sensitivities to the serum (Guo et al., 2005), complement (Murray et al., 2006) and bacteriophages (Iguchi et al., 2007), and the function of T3SSs (West et al., 2005). As such, ICC219 and the two O55 strains representing the other lineages (TB182A and WC416) provide good experimental organisms to examine how difference in $\mathrm{O}$-antigen chain lengths might affect virulence potential.

\section{ACKNOWLEDGEMENTS}

We gratefully acknowledge Stuart Knutton and Luis Trabulsi for providing bacterial strains. We thank Ken Kurokawa for helpful discussions and suggestions, and Noriko Kanemaru, Akemi Yoshida and Yumiko Takeshita for technical assistance. This work was supported by Grants-in-Aid for Scientific Research on Priority Areas (Applied Genomics), for the 21st Century COE Program and for Young Scientists (B) (no. 19790325) from the Ministry of Education, Culture, Sports, Science and Technology of Japan, and by a Grant-in-Aid of Ministry of Health, Labor and Welfare of Japan (H17-Sinkou-ippan-019). 


\section{REFERENCES}

Altschul, S. F., Madden, T. L., Schaffer, A. A., Zhang, J., Zhang, Z., Miller, W. \& Lipman, D. J. (1997). Gapped BLAST and PSI-BLAST: a new generation of protein database search programs. Nucleic Acids Res 25, 3389-3402.

Blanco, M., Blanco, J. E., Dahbi, G., Alonso, M. P., Mora, A., Coira, M. A., Madrid, C., Juárez, A., Bernárdez, M. I. \& other authors (2006). Identification of two new intimin types in atypical enteropathogenic Escherichia coli. Int Microbiol 9, 103-110.

Bokete, T. N., Whittam, T. S., Wilson, R. A., Clausen, C. R., O'Callahan, C. M., Moseley, S. L., Fritsche, T. R. \& Tarr, P. I. (1997). Genetic and phenotypic analysis of Escherichia coli with enteropathogenic characteristics isolated from Seattle children. J Infect Dis 175, 1382-1389.

Cebula, T. A., Payne, W. L. \& Feng, P. (1995). Simultaneous identification of strains of Escherichia coli serotype O157:H7 and their Shiga-like toxin type by mismatch amplification mutation assaymultiplex PCR. J Clin Microbiol 33, 248-250.

Cunneen, M. M. \& Reeves, P. R. (2007). The Yersinia kristensenii O11 $\mathrm{O}$-antigen gene cluster was acquired by lateral gene transfer and incorporated at a novel chromosomal locus. Mol Biol Evol 24, $1355-1365$.

Curd, H., Liu, D. \& Reeves, P. (1998). Relationships among the Oantigen gene clusters of Salmonella enterica groups B, D1, D2, and D3. J Bacteriol 180, 1002-1007.

de Hoon, M. J., Imoto, S., Nolan, J. \& Miyano, S. (2004). Open source clustering software. Bioinformatics 20, 1453-1454.

DeVinney, R., Stein, M., Reinscheid, D., Abe, A., Ruschkowski, S. \& Finlay, B. (1999). Enterohemorrhagic Escherichia coli O157:H7 produces Tir, which is translocated to the host cell membrane but is not tyrosine phosphorylated. Infect Immun 67, 2389-2398.

Dixon, D. A. \& Kowalczykowski, S. C. (1993). The recombination hotspot chi is a regulatory sequence that acts by attenuating the nuclease activity of the E. coli RecBCD enzyme. Cell 73, 87-96.

Donnenberg, M. S., Kaper, J. B. \& Finlay, B. B. (1997). Interactions between enteropathogenic Escherichia coli and host epithelial cells. Trends Microbiol 5, 109-114.

Elliott, S. J., Wainwright, L. A., McDaniel, T. K., Jarvis, K. G., Deng, Y. Y., Lai, L. C., McNamara, B. P., Donnenberg, M. S. \& Kaper, J. B. (1998). The complete sequence of the locus of enterocyte effacement (LEE) from enteropathogenic Escherichia coli E2348/69. Mol Microbiol 28, 1-4.

Fegan, N., Barlow, R. \& Gobius, K. (2006). Escherichia coli O157 somatic antigen is present in an isolate of E. fergusonii. Curr Microbiol 52, 482-486.

Fetherston, J. D., Lillard, J. W., Jr \& Perry, R. D. (1995). Analysis of the pesticin receptor from Yersinia pestis: role in iron-deficient growth and possible regulation by its siderophore. J Bacteriol 177, 1824-1833.

Franke, J., Franke, S., Schmidt, H., Schwarzkopf, A., Wieler, L., Baljer, G., Beutin, L. \& Karch, H. (1994). Nucleotide sequence analysis of enteropathogenic Escherichia coli (EPEC) adherence factor probe and development of PCR for rapid detection of EPEC harboring virulence plasmids. J Clin Microbiol 32, 2460-2463.

Garmendia, J., Phillips, A. D., Carlier, M. F., Chong, Y., Schüller, S., Marches, O., Dahan, S., Oswald, E., Shaw, R. K. \& other authors (2004). TccP is an enterohaemorrhagic Escherichia coli O157: H7 type III effector protein that couples Tir to the actin-cytoskeleton. Cell Microbiol 6, 1167-1183.

Garmendia, J., Ren, Z., Tennant, S., Midolli Viera, M. A., Chong, Y., Whale, A., Azzopardi, K., Dahan, S., Sircili, M. P. \& other authors (2005). Distribution of $t c c P$ in clinical enterohemorrhagic and enteropathogenic Escherichia coli isolates. J Clin Microbiol 43, 5715-5720.

Girardeau, J. P., Dalmasso, A., Bertin, Y., Ducrot, C., Bord, S., Livrelli, V., Vernozy-Rozand, C. \& Martin, C. (2005). Association of virulence genotype with phylogenetic background in comparison to different seropathotypes of Shiga toxin-producing Escherichia coli isolates. J Clin Microbiol 43, 6098-6107.

Gruenheid, S., DeVinney, R., Bladt, F., Goosney, D., Gelkop, S., Gish, G., Pawson, T. \& Finlay, B. (2001). Enteropathogenic E. coli Tir binds Nck to initiate actin pedestal formation in host cells. Nat Cell Biol 3, 856-859.

Gunzburg, S. T., Tornieporth, N. G. \& Riley, L. W. (1995). Identification of enteropathogenic Escherichia coli by PCR-based detection of the bundle-forming pilus gene. J Clin Microbiol 33, 1375-1377.

Guo, H., Yi, W., Shao, J., Lu, Y., Zhang, W., Song, J. \& Wang, P. (2005). Molecular analysis of the $\mathrm{O}$-antigen gene cluster of Escherichia coli O86:B7 and characterization of the chain length determinant gene (wzz). Appl Environ Microbiol 71, 7995-8001.

Hayashi, T., Makino, K., Ohnishi, M., Kurokawa, K., Ishii, K., Yokoyama, K., Han, C. G., Ohtsubo, E., Nakayama, K. \& other authors (2001). Complete genome sequence of enterohemorrhagic Escherichia coli $\mathrm{O} 157: \mathrm{H} 7$ and genomic comparison with a laboratory strain K-12. DNA Res 8, 11-22.

Hyma, K. E., Lacher, D. W., Nelson, A. M., Bumbaugh, A. C., Janda, J. M., Strockbine, N. A., Young, V. B. \& Whittam, T. S. (2005). Evolutionary genetics of a new pathogenic Escherichia species: Escherichia albertii and related Shigella boydii strains. J Bacteriol 187, 619-628.

Iguchi, A., Iyoda, S., Watanabe, H. \& Osawa, R. (2007). O side chain deficiency enhances sensitivity of Escherichia coli to Shiga toxin 2converting bacteriophages. Curr Microbiol 54, 14-19.

Kaper, J. B. (1998). Enterohemorrhagic Escherichia coli. Curr Opin Microbiol 1, 103-108.

Karch, H., Bohm, H., Schmidt, H., Gunzer, F., Aleksic, S. \& Heesemann, J. (1993). Clonal structure and pathogenicity of Shigalike toxin-producing, sorbitol-fermenting Escherichia coli $\mathrm{O} 157: \mathrm{H}$. J Clin Microbiol 31, 1200-1205.

Kenny, B. (1999). Phosphorylation of tyrosine 474 of the enteropathogenic Escherichia coli (EPEC) Tir receptor molecule is essential for actin nucleating activity and is preceded by additional host modifications. Mol Microbiol 31, 1229-1241.

Kim, C. C., Joyce, E. A., Chan, K. \& Falkow, S. (2002). Improved analytical methods for microarray-based genome-composition analysis. Genome Biol 3, RESEARCH0065.

Kumar, S., Tamura, K. \& Nei, M. (2004). MEGA3: integrated software for Molecular Evolutionary Genetics Analysis and sequence alignment. Brief Bioinform 5, 150-163.

Lacher, D. W., Steinsland, H. \& Whittam, T. S. (2006). Allelic subtyping of the intimin locus (eae) of pathogenic Escherichia coli by fluorescent RFLP. FEMS Microbiol Lett 261, 80-87.

Lawrence, J. G. \& Ochman, H. (1998). Molecular archaeology of the Escherichia coli genome. Proc Natl Acad Sci U S A 95, 9413-9417.

McGraw, E. A., Li, J., Selander, R. K. \& Whittam, T. S. (1999). Molecular evolution and mosaic structure of alpha, beta, and gamma intimins of pathogenic Escherichia coli. Mol Biol Evol 16, 12-22.

Mellies, J. L., Elliott, S. J., Sperandio, V., Donnenberg, M. S. \& Kaper, J. B. (1999). The Per regulon of enteropathogenic Escherichia coli: identification of a regulatory cascade and a novel transcriptional activator, the locus of enterocyte effacement (LEE)-encoded regulator (Ler). Mol Microbiol 33, 296-306. 
Mooi, F. R. \& Bik, E. M. (1997). The evolution of epidemic Vibrio cholerae strains. Trends Microbiol 5, 161-165.

Murray, G. L., Attridge, S. R. \& Morona, R. (2006). Altering the length of the lipopolysaccharide $\mathrm{O}$ antigen has an impact on the interaction of Salmonella enterica serovar Typhimurium with macrophages and complement. J Bacteriol 188, 2735-2739.

Nataro, J. P. \& Kaper, J. B. (1998). Diarrheagenic Escherichia coli. Clin Microbiol Rev 11, 142-201.

Nataro, J. P., Yikang, D., Yingkang, D. \& Walker, K. (1994). AggR, a transcriptional activator of aggregative adherence fimbria I expression in enteroaggregative Escherichia coli. J Bacteriol 176, 4691-4699.

O'Connell, C., Pattee, P. A. \& Foster, T. J. (1993). Sequence and mapping of the aroA gene of Staphylococcus aureus 8325-4. J Gen Microbiol 139, 1449-1460.

Ogura, Y., Kurokawa, K., Ooka, T., Tahiro, K., Tobe, T., Ohnishi, M., Nakayama, K., Morimoto, T., Terajima, J. \& other authors (2006). Complexity of the genomic diversity in enterohemorrhagic Escherichia coli $\mathrm{O} 157$ revealed by the combinational use of the O157 Sakai OligoDNA microarray and the whole genome PCR scanning. DNA Res 13, 3-14.

Ogura, Y., Ooka, T., Whale, A., Garmendia, J., Beutin, L., Tennant, S., Krause, G., Morabito, S., Chinen, I. \& other authors (2007). TccP2 of O157: H7 and non-O157 enterohemorrhagic Escherichia coli (EHEC): challenging the dogma of EHEC-induced actin polymerization. Infect Immun 75, 604-612.

Ohnishi, M., Terajima, J., Kurokawa, K., Nakayama, K., Murata, T., Tamura, K., Ogura, Y., Watanabe, H. \& Hayashi, T. (2002). Genomic diversity of enterohemorrhagic Escherichia coli O157 revealed by whole genome PCR scanning. Proc Natl Acad Sci U S A 99, 17043-17048.

Ooka, T., Vieira, M., Ogura, Y., Beutin, L., La Ragione, R., van Diemen, P. M., Stevens, M. P., Aktan, I., Cawthraw, S. \& other authors (2007). Characterization of tccP2 carried by atypical enteropathogenic Escherichia coli. FEMS Microbiol Lett 271, 126-135.

Pupo, G. M., Karaolis, D. K., Lan, R. \& Reeves, P. R. (1997). Evolutionary relationships among pathogenic and nonpathogenic Escherichia coli strains inferred from multilocus enzyme electrophoresis and $m d h$ sequence studies. Infect Immun 65, 2685-2692.

Ramachandran, V., Brett, K., Hornitzky, M., Dowton, M., Bettelheim, K., Walker, M. \& Djordjevic, S. (2003). Distribution of intimin subtypes among Escherichia coli isolates from ruminant and human sources. JClin Microbiol 41, 5022-5032.

Reeves, P. R., Hobbs, M., Valvano, M. A., Skurnik, M., Whitfield, C., Coplin, D., Kido, N., Klena, J., Maskell, D. \& other authors (1996). Bacterial polysaccharide synthesis and gene nomenclature. Trends Microbiol 4, 495-503.

Reid, S. D., Herbelin, C. J., Bumbaugh, A. C., Selander, R. K. \& Whittam, T. S. (2000). Parallel evolution of virulence in pathogenic Escherichia coli. Nature 406, 64-67.

Saldanha, A. J. (2004). Java TreeView - extensible visualization of microarray data. Bioinformatics 20, 3246-3248.

Scheutz, F., Cheasty, T., Woodward, D. \& Smith, H. (2004). Designation of O174 and O175 to temporary O groups OX3 and OX7, and six new E. coli $\mathrm{O}$ groups that include Verocytotoxinproducing E. coli (VTEC): O176, O177, O178, O179, O180 and O181. APMIS 112, 569-584.
Schmidt, H., Russmann, H. \& Karch, H. (1993). Virulence determinants in nontoxinogenic Escherichia coli O157 strains that cause infantile diarrhea. Infect Immun 61, 4894-4898.

Schubert, S., Rakin, A., Karch, H., Carniel, E. \& Heesemann, J. (1998). Prevalence of the "high-pathogenicity island" of Yersinia species among Escherichia coli strains that are pathogenic to humans. Infect Immun 66, 480-485.

Stroeher, U. H. \& Manning, P. A. (1997). Vibrio cholerae serotype O139: swapping genes for surface polysaccharide biosynthesis. Trends Microbiol 5, 178-180.

Stroeher, U. H., Jedani, K. E. \& Manning, P. A. (1998). Genetic organization of the regions associated with surface polysaccharide synthesis in Vibrio cholerae O1, O139 and Vibrio anguillarum $\mathrm{O} 1$ and O2: a review. Gene 223, 269-282.

Sugiyama, T., Kido, N., Kato, Y., Koide, N., Yoshida, T. \& Yokochi, T. (1998). Generation of Escherichia coli O9a serotype, a subtype of $E$. coli O9, by transfer of the $w b^{\star}$ gene cluster of Klebsiella O3 into E. coli via recombination. J Bacteriol 180, 2775-2778.

Tarr, C. L. \& Whittam, T. S. (2002). Molecular evolution of the intimin gene in O111 clones of pathogenic Escherichia coli. J Bacteriol 184, 479-487.

Thompson, J. D., Higgins, D. G. \& Gibson, T. J. (1994). CLUSTAL W: improving the sensitivity of progressive multiple sequence alignment through sequence weighting, position-specific gap penalties and weight matrix choice. Nucleic Acids Res 22, 4673-4680.

Trabulsi, L. R., Keller, R. \& Tardelli Gomes, T. A. (2002). Typical and atypical enteropathogenic Escherichia coli. Emerg Infect Dis 8, 508-513.

Wang, L., Rothemund, D., Curd, H. \& Reeves, P. (2000). Sequence diversity of the Escherichia coli $\mathrm{H} 7$ fliC genes: implication for a DNAbased typing scheme for E. coli O157:H7. J Clin Microbiol 38, 1786-1790.

Wang, L., Huskic, S., Cisterne, A., Rothemund, D. \& Reeves, P. (2002). The O-antigen gene cluster of Escherichia coli O55:H7 and identification of a new UDP-GlcNAc C4 epimerase gene. J Bacteriol 184, 2620-2625.

West, N. P., Sansonetti, P., Mounier, J., Exley, R. M., Parsot, C., Guadagnini, S., Prévost, M. C., Prochnicka-Chalufour, A., Delepierre, M. \& other authors (2005). Optimization of virulence functions through glucosylation of Shigella LPS. Science 307, 1313-1317.

Whittam, T. S., Wolfe, M. L., Wachsmuth, I. K., Orskov, F., Orskov, I. \& Wilson, R. A. (1993). Clonal relationships among Escherichia coli strains that cause hemorrhagic colitis and infantile diarrhea. Infect Immun 61, 1619-1629.

Wick, L. M., Qi, W., Lacher, D. W. \& Whittam, T. S. (2005). Evolution of genomic content in the stepwise emergence of Escherichia coli O157: H7. J Bacteriol 187, 1783-1791.

Xiang, S. H., Hobbs, M. \& Reeves, P. R. (1994). Molecular analysis of the $r f b$ gene cluster of a group D2 Salmonella enterica strain: evidence for its origin from an insertion sequence-mediated recombination event between group E and D1 strains. J Bacteriol 176, 4357-4365.

Yamamoto, T. \& Nakazawa, M. (1997). Detection and sequences of the enteroaggregative Escherichia coli heat-stable enterotoxin 1 gene in enterotoxigenic E. coli strains isolated from piglets and calves with diarrhea. J Clin Microbiol 35, 223-227.

Edited by: I. R. Henderson 